\title{
SOSIALISASI PEMBUATAN ABON IKAN TONGKOL DI KELURAHAN RAMBUNG DALAM, KECAMATAN BINJAI SELATAN KOTA BINJAI
}

\author{
Hasrita $^{1^{*}}$, Maswita ${ }^{2}$, Arifah Pratami ${ }^{3}$ \\ ${ }^{1}$ Program Studi Magister Manajemen, Fakultas Ekonomi, Universitas Islam Sumatera Utara Jl. \\ Sisingamangaraja Exemplary, Kelurahan Teladan Barat,Kecamatan Medan Kota 20217 \\ ${ }^{2}$ Program Studi Hukum, Fakultas Hukum, Universitas Al-Azhar, Jl. Pintu Air IV No.214, Kwala \\ Bekala, Kec. Medan Johor, Kota Medan, Sumatera Utara 20143 \\ ${ }^{3}$ Program Studi Ekonomi Syariah, Fakultas Agama Islam, Universitas Islam Sumatera Utara Jl. \\ Sisingamangaraja Exemplary, Kelurahan Teladan Barat,Kecamatan Medan Kota 20217 \\ *Maswita30@gmail.com
}

\begin{abstract}
ABSTRAK. Kegiatan pengabdian masyarakat ini, bertujuan untuk memberikan pengetahuan kepada ibu-ibu rumah tangga di Kelurahan Rambung Dalam Kecamatan Binjai Selatan Kota Binjai dalam rangka pembuatan abon dari ikan tongkol sebagai salah satu cara untuk memenuhi kebutuhan sendiri. Disamping itu pembuatan abon ikan ini dilakukan sebagai alternatif usaha dalam membantu ekonomi rumah tangga dimasa sulit seperti saat pandemi ini. Pembuatan ikan tongkol yang diolah menjadi abon, dipraktekkan bersama sama ibu-ibu tersebut dengan protokol kesehatan di masa covid seperti sekarang ini. Selain menambah penghasilan rumah tangga, pembuatan abon ikan dapat menambah wawasan para warga terutama ibu-ibu yang aktif berpartisipasi di Kelurahan Rambung Dalam Kecamatan Binjai Selatan Kota Binjai. Dan diharapkan warga kelurahan Rambong Dalam akan mampu membuat abon ikan secara mandiri.
\end{abstract}

Kata kunci: ibu- ibu rumah tangga, pembuatan abon, ekonomi rumahtangga

ABSTRACT. This community service activity aims to provide knowledge to housewives in Rambung Dalam Village, South Binjai District Binjai Municipality in making shredded tuna from tuna as a way to meet their own needs. Besides, the making of shredded fish in done as an alternative buseness in helping the household economy in difficult times such as during this pandemic. The manufacture of tuna which is processed in to shredded fish will be practiced together with the mothers with health protocols during the current covid period. In addition to increasing household income, making fish floss can add to the insight of residents, especially mothers who actively perticipate in Rambung Dalam Village, South Binjai District, Binjai Municipality. And it is hoped that the residents of the Rambong Dalam village will be able to make shredded fish independently

Keywords: housewives, floss making, household economy

Terima 5 Januari 2022 Terima dan di revisi 6 Januari 2022 Disetujui 11 Januari 2022

\section{PENDAHULUAN}

Berada dalam kondisi pandemi saat ini, banyak produk usaha yang gagal terjual di pasar yang di sebabkan oleh tidak adanya kemampuan masyarakat untuk membeli, selain itu keterbatasan pengetahuan dan kurangnya motivasi untuk berkereasi, ikut menjadi faktor penyebab tidak mampunya ibu-ibu rumah tangga untuk membuat sesuatu yang berbeda sebagai alternatif dalam memenuhi kebutuhan lauk makan sehari-hari. baik untuk keluarga sendiri maupun untuk mengatasi ekonomi rumah tangga. Pembuatan ikan menjadi abon adalah salah satu usaha menjadikan bahan ikan bertahan lama untuk di konsumsi keluarga. Selain itu membuat ikan sebagai abon dapat dipasarkan sebagai usaha kecil dan menengah. Sebenarnya produk abon ikan merupakan selera masyarakat Indonesai pada umunya, tak terkecuali warga Kelurahan Rambung Dalam Kecamatan Binjai Selatan kota Binjai. Faktor lain adalah, wabah covid-19 yang serta merta meruntuhkan sendi-sendi perekonomian keluarga, diantaranya banyak para pekerja yang di rumahkan, namun para usaha kecil 
tidak berhenti berinovasi dan berkereasi. Dalam rangka kerjasama pengabdian masyarakat Fakultas Keguruan Ilmu Pendidikan UISU dan Kelurahan Rambung Dalam Kecamatan Binjai yang sudah disepekati pada tahun 2021 maka salah satu aplikasi dari kerjasama pengabdian tersebut adalah sosialisasi dan praktek pembuatan abon dari ikan tongkol. Adapun alasan, ikan tongkol dijadikan sebagai bahan dasar, karena selalu lebih murah harganya dibanding ikan jenis lainnya, namun tidak mengurangi citarasa dan kualitas abon ikan tersebut. Abon merupakan salah satu jenis makanan berbahan dasar daging ikan, dan biasanya dikonsumsi sebagai lauk makan dengan cara menaburkannya di atas nasi untuk disantap bersama keluarga atau juga dapat dijadikan sebagai cemilian. Rasa dan aroma Abon ikan tidak kalah dengan abon daging yang ada di pasar tradisional ataupun di pasar modern. Lagi pula peluang usaha abon ikan di saat covid ini cukup menjanjikan, sehingga bisa membantu memenuhi kebutuhan lauk keluarga dan juga dapat dijadikan sebagai peluang usaha perekenomian keluarga. Sebagaimana di ketahui Pemerintah Indonesia akhirnya resmi menetapkan ikan jadi komoditas terkini yang masuk sebagai bahan pokok dan barang penting melalui Peraturan Presiden No 71 Tahun 2015 tentang Penetapan dan Penyimpanan Barang Kebutuhan Pokok dan Barang Penting. Tingginya kandungan protein pada abon ikan berfungsi untuk pertumbuhan dan pembentukan massa otot daripada tubuh manusia. Selanjutnya mengenai ikan juga terdapat dalam Peraturan Menteri Kelautan dan Perikanan Republik Indoensia nomor 67/Permen-KP/2018 Tentang Usaha Pengelolaan Ikan. Abon ikan memiliki kandungan zat besi yang tinggi dan hal ini berfungsi untuk memperlancar peredaran darah dan mempercepat pembentukan sel darah merah. Apabila kedua hal ini dapat berfungsi normal seperti lazimnya, maka tubuh manusia akan tetap sehat dan dapat meminimalisir risiko anemia pula. Selain itu, adanya kandungan lemak pada abon ikan juga berfungsi untuk membuat orang yang memakannya merasa kenyang dalam waktu yang lama. Ikan adalah sumber protein yang tinggi, selain rasanya yang lezat, makanan laut atau boga bahari digemari karena mengandung banyak nutrisi yang baik bagi tubuh. Kandungan protein, asam lemak omega-3, serta vitamin dan mineral makanan laut, sehingga penting untuk disajikan menu dalam makanan keluarga. Ikan tongkol termasuk kedalam jenis ikan ekonomis penting di Indonesia, karena peranannya dalam usaha perbaikan gizi dalam menu makanan rakyat serta dapat meningkatkan pendapatan masyarakat. Jika ikan hanya dikonsumsi seperti biasa maka tidak akan bertahan lama, namun dengan adanya kreasi dari pembuatan ikan menjadi abon yang lebih inovatif dan bebas pengawet serta tahan lama, menyebabkan makanan ini sangat berfungsi terutama di masa covid. Maka dari itu pelatihan dan keterampilan proses pembuatan abon ikan yang lezat cita rasanya dan tahan lama akan membantu para ibu- ibu rumah tangga dalam mengatur belanja keluarga kerena harga ikan selalu berubah ubah apalagi di musim pasang mati atau musim badai di perairan pantai, harga ikan sangat melonjak tinggi, sehingga sulit untuk membeli ikan. Manakala jenis ikan adalah satu dari jenis bahan makanan yang dapat mengatasi kekurangan protein bagi kebutuhan nutrisi keluarga. Adapun tujuan dari pengabdian ini adalah :

1. Memberikan pengetahuan kepada kaum ibu warga masyarakat Kelurahan Rambung untuk memiliki ketrampilan dalam membuiat abon ikan

2. Supaya peserta memiliki kemampuan berinovasi dengan bahan baku ikan yang dapat bertahan dalam waktu yang lama untuk kebutuhan mereka sendiri.

3. Dapat juga menjadi sumber mata pencaharian antar tetangga atau sambil mengajarkan pada orang lain agar bisa membuka usaha penjualan abon.

4. Mengisi waktu luang, yang lebih bermanfaat

\section{METODE}

Metode yang digunakan dalam kegiatan ini adalah ceramah/penyuluhan, yang dilaksanakan dari pukul 8,30 hingga pukul 10.00 pagi dan diteruskan praktek pembuatan abon bersama dengan peserta pukul 10.00 hingga pukul 12.00 siang. Bertempat di balai Kelurahan Rambong Dalam dan dihadiri oleh ibu-ibu warga Kelurahan Rambung Dalam sebanyak 22 orang. Di masa pandemi, pengolahan abon ikan cukup mendapat peminat, dan lagi makanan jenis abon ini awet, mudah dibuat untuk dimakan sendiri, dan 
untuk diperjual belikan. Orang tidak akan ragu untuk membelinya, selain harganya cukup murah juga menghemat waktu karena tidak harus keluar rumah setiap hari untuk berbelanja membeli ikan buat keluarga. Masa pandemi ini sulit bagi kita untuk selalu berbelanja ke pasar. Seandainya ke pasar haruslah berhati-hati walau hanya untuk belanja keperluan rumah tangga. Kondisi jaga jarak, cuci tangan dan menggunakan masker kadang terasa agak riskan, jika berbelanja ke pasar untuk memenuhi kebutuhan, sehingga selalu memilih hal yang praktis dan ekonomis. Pelaksanaan kegiatan pengabdian melalui beberapa tahap diantaranya sebagai berikut;

1. Penyuluhan, memberikan pengatahuan kepada ibu-ibu yang berpartisipasi di Kelurahan Rambung Dalam, terutama yang ingin menambah pengetahuan dalam pembuatan abon ikan tongkol dan juga yang ingin menambah penghasilan ekonomi keluarga di masa pandemi. Para peserta akan mendapatkan informasi tentang cara membuatan abon ikan dari proses pengolahan, hinggga abon siap untuk di makan. Bagi yang ingin berkreasi dalam keahlian yang di milikinya, tetap akan di fasilitasi untuk memperoleh informasi dan teknik cara pembuatan abon ikan. Dalam penyuluhan yang dilaksanakan, penyuluh dengan senang hati memberikan jawaban jika peserta ada yang bertanya berkaitan dengan materi.

2. Pelatihan ini juga memperaktekkan bagaimana memilih ikan yang masih segar sebagai bahan baku untuk membuat abon hingga menghasilkan abon yang baik kwalitasnya. Dan setiap warga yang ikut dalam kegiatan penyuluhan diharapkan ikut terlibat langsung dalam praktek, agar mendapatkan pengetahuan dan ktrampilan membuat abon ikan sebagai upayah meningkatkan pendapatan keluarga di Kelurahan Rambung Dalam khususnya. Penyuluhan dan pelatihan ini dilaksanakan satu hari bertempat di balai Kelurahan Rambung Dalam dalam dua sesi. Sesi pertama mendengarkan materi pelatihan cara pembuatan, bahan dan alat yang digunakan sperti memilih ikan segar dan bahan lain seperti cabe, kunyit, laos, jahe, terasi, garam, penyedap, bawang putih, bawang merah, jinten manis, gula pasir dan minyak kelapa.
Kemudian bagaimana cara membersihkan ikan terutama bahagian dalamnya sehingga ikan tidak mengeluarkan darah lalu ikan di masak memakai garam secukupnya lalu di dinginkan selama lebih kurang 15 menit. Setelah itu ikan di bersihkan kembali dengan cara tulang ikan di buang, warna coklat ikan dan kepala ikan tidak diikut sertakan dan kulit ikan dibuang, hanya daging ikan yang berwarna putih saja yang diambil. Ikan yang sudah bersih, ditumbuk dan dicampur dengan bumbu yang sudah dihaluskan, lalu di goreng sampai kering

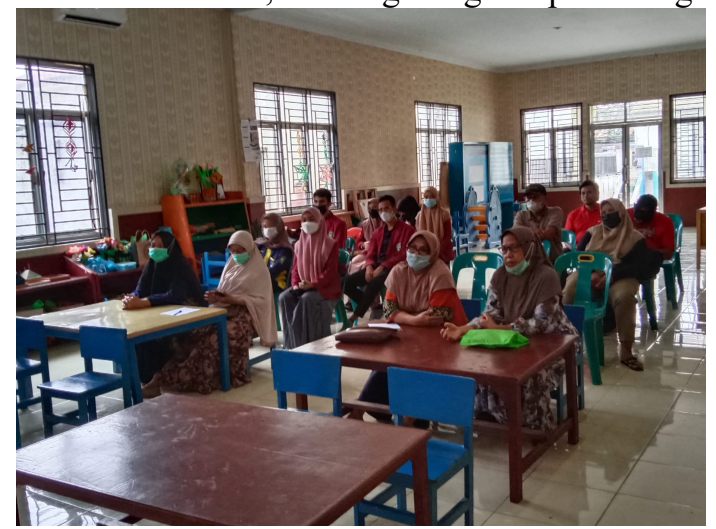

Gambar 1 Penyuluhan (Sumber: data diolah, 2021)

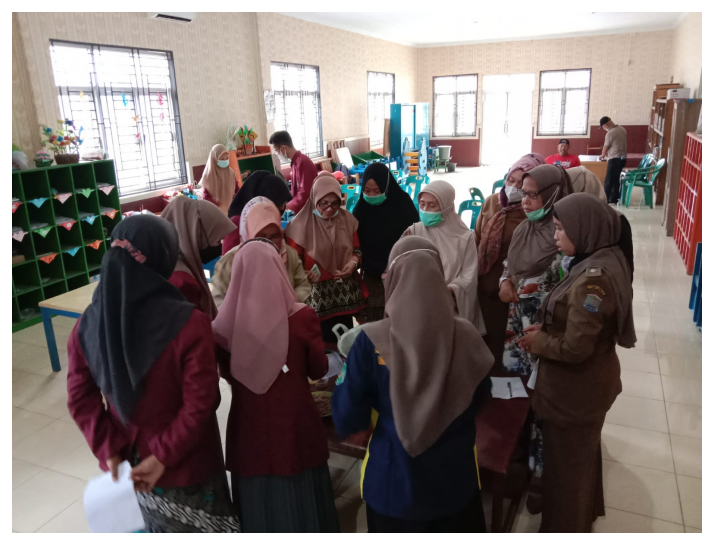

Gambar 2 Praktik pembuatan abon (Sumber: data diolah, 2021)

\section{HASIL DAN PEMBAHASAN}

Munculnya bencana virus corona yang mendunia ini, secara langsung menimbulkan krisis ekonomi menyeluruh. Karena virus ini memaksa masyarakat untuk menjaga diri dengan banyak berdiam dirumah dan melakukan karantina secara mandiri untuk memutus rantai penyebaran covid-19. Sehingga tim penyuluh memberikan arahan supaya peserta dalam penyuluhan pembuatan abon ikan dengan prtokol kesehatan yang ketat. Penyuluhan tentang pembuatan abon 
ikan berjalan dengan baik, para peserta antusias mengikutinya, hal ini terbukti banyak diantara mereka mengajukan pertanyaan. Diantara mereka ada yang ingin melaksanakannya dirumah masing-masing dan ada juga yang mau membuat secara berkelompok supaya dapat berbagi pengetahuan yang sudah diperoleh. Pembuatan abon ikan merupakan hal yang baru bagi peserta sehingga penyuluhan berupa edukasi kepada ibu ibu yang tidak memiliki penghasilan dapat menjadikan abon ikan sebagai salah satu usaha menambah penghasilan. Dengan usaha tersebut dapat membantu meningkatkan ekonomi keluarga di Kelurahan Rambung Dalam kecamatan Binjai Selatan Kota Binjai

\section{SIMPULAN}

Melalui kegiatan pengabdian kepada masyarakat ini dapat disimpulkan sebagai berikut :

1. Ibu-ibu yang aktif berpartisipasi khususnya dan masyarakat Kelurahan Rambung dalam pada umumnya memiliki pengetahuan dan skill untuk membuat abon ikan tongkol.

2. Memiliki kemampuan berinovasi dengan bahan baku yang lebih murah untuk menjadikan bahan lauk-pauk yang dapat bertahan lama.

3. Bisa menjadi sumber mata pencaharian antar teman atau menjual dari rumah ke rumah sambil mengajarkan pada orang lain agar bisa membuka usaha abon ikan tongkol ataupun dengan jenis ikan lainnya

4. Mengisi waktu luang, jika ada kesibukan tentu waktu senggang bisa dimanfaatkan bagi diri dan orang lain dengan cara mengajarkannya kembali

\section{UCAPAN TERIMAKASIH}

Kami selaku penyuluh mengucapkan terimakasih kepada Lurah Kelurahan Rambung Dalam yang memfasilitasi terlaksananya pengabdian ini sehingga kerjasama yang sudah disepakati dapat berlanjut pada tahap berikutnya dan pada kegiatan yang lainnya

\section{DAFTAR PUSTAKA}

D Nurani, A Amar, M Muhami, S. M. (2011). Modul Pembelajaran Bidang Pangan: Pengolahan Hasil Pertanian, Perikanan,
Dan Kelautan Kementrian Agama Republik Indonesia.

Hafiludin.( 2015). Analisis Kandungan Gizi Ikan Bandeng Yang Berasal Dari Habitat Yang Berbeda . Jurusan ilmu Kelautan universitas Trunojoyo Madura. Jurnal kelautan vol 8 nomor 1 hal: 40 .

Hafiludin. (2011). Karakteristik Proksimat dan Kandungan Senyawa Kimia Daging Putih dan Daging Merah Ikan Tongkol (Euthynnus Affinis). Jurnal Kelautan, 4(1), 1-10.

Suriani Rauf (2007) Pengaruh Pemberian Abon Ikan Terhadap Perubahan Status Gizi Anak Gizi Kurang Umur 24-59 Bulan (Studi di Kabupaten Pangkep Sulawesi Selatan). Semarang : Tesis Mster.

T., Yuwono,T., Paulus, T. F., Azizah, N., \& Ramadhani, A. P. (2016). Rekomendasi Teknologi dan Perikanan. Jakarta: Badan Penelitian dan Pengembangan .

Peraturan menteri Kelautan dan Perikanan Republik Indoensia nomor 67/PermenKP/2018 Tentang Usaha Pengelolaan Ikan.

Peraturan Presiden No 71 Tahun 2015 tentang Penetapan dan Penyimpanan Barang Kebutuhan Pokok dan Barang Penting. 